\title{
THE FUNDAMENTAL RIGHT TO THE INFORMATION AND TRANSPARENCY IN THE ANTICORRUPTION LAW: IS IT GOING FORWARD OR BACKWARD?
}

\author{
O DIREITO FUNDAMENTAL Aं INFORMAÇÃO E \\ TRANSPAR ENNCIA NA LEI ANTICORRUPÇÃO: AVANÇO OU \\ RETROCESSO?
}

\author{
Denise Bittencourt Friedrich ${ }^{1}$ \\ Fábio Roque Sbardelotto ${ }^{1}$
}

\begin{abstract}
Recebido em: 17/08/2016 Aceito em: 22/09/2016

d-friedrich@hotmail.com fabiosbardelotto@gmail.com
\end{abstract}

\begin{abstract}
The question which motivated this work refers to the fact whether the rules anticorruption law (Law 12.846/13) and its respective decree represents a step forward or backward with the scope of information and transparency of companies that contract with the government. This approach has its origin in the necessity of thinking ways to ensure the ethics in government procurements, especially in the private sector, which is part the contractual legal relationship. The method used in this work is the hypothetical-deductive method due the presented problem, there is a chance that the republican values entered in the constitution, the effectiveness of the rights and duties to information goes through an effort to extend it to a private initiative in contracts with the government, given the public interest involved, and from this point, it will be promoting the principle of public morality. To answer this question, it was used the analysis of the anticorruption law, given such concern for the ethical management of the companies that contract with the government. However, the scope of this work is to investigate how this legal tool as well as the decree that regulated it treated the transparency questions related with the managements of such companies. It was noticed that the corruption regulation directed to the private sector is a great step forward, but it cannot be taken as a conclusion of this work. The treatment given by the anticorruption law was lacked, the situation that it was remained in its regulated decree has backwards points.
\end{abstract}

Keywords: Transparency. Information. Public Contracts.

Resumo: A pergunta que motivou este trabalho refere-se ao fato de, se a regulamentação da Lei Anticorrupção (Lei 12.846/13) e o seu respectivo decreto, representam um avanço ou retrocesso frente ao dever de informação e transparência das empresas que contratam com o Poder Público? Essa abordagem tem sua origem na necessidade de se pensar instrumentos para assegurar a ética nas contratações públicas, notadamente ao setor privado que faz parte da relação jurídica contratual. O método eleito foi o hipotético-dedutivo, pois a partir da problemática apresentada, existe a hipótese de que pelos valores republicanos inseridos no texto constitucional, a efetividade do direito/dever à informação passa por um esforço hermenêutico em ampliá-lo à inciativa privada nos contratos com o poder público, haja vista o interesse público envolvido, e a partir desta posição, estar-se-á promovendo o princípio da moralidade pública. Para responder esta indagação, recorreu-se à análise da Lei anticorrupção, haja vista que ela tem uma notória preocupação com a gestão ética das empresas que contratam com o poder público, porém, se quer investigar como esta ferramenta jurídica, bem como o decreto que a regulamentou, tratou a questão da transparência na gestão de tais empresas. Percebe-se que a regulamentação da corrupção dirigida a inciativa privada foi um avanço inegável, mas, não se pode deixar de concluir que quanto ao objeto deste trabalho (o dever de informação e transparência), o tratamento dado pela Lei Anticorrupção foi carente, situação que se manteve no decreto que a regulamentou, e assim, sob esse aspecto, houve um retrocesso.

Palavras-chave: Transparência. Informação. Contratos Públicos.

\section{INTRODUÇÃO}

\footnotetext{
${ }^{1}$ Universidade de Santa Cruz do Sul - UNISC - Santa Cruz do Sul - Rio Grande do Sul - Brasil.
} 
The presented subject is the way how the fundamental law reports, unfolding the transparency applied in the private sector, specially for those who constantly receive funds by the public treasure, from of public construction, whether by selling products or services to the government either by concessionaires or licensees of public services. In fact, the purpose is to expand the scope of information and transparency for legal entities that have, somehow, legal contractual relation with the government. It is believed that through this way it will move toward to ensure the ethical sustainability of legal relations in which the state forms part.

The original document of the contract law and public procurement (federal law 8666/93) had not provided, among the basic principles of procurement, the sustainable development ${ }^{2}$. However, in 2010, a norm was included in the legal document, with the scope of giving notoriety and impose the most advantageous tender of the administration by bidding among companies. The point is that in the document the meaning that was given is that the "sustainable project" has to be aimed to environmental sustainability and not turned only to the criteria of economics and financials, therefore it sets the government to engage with people who are concerned to offer products and services with sustainable purposes.

The meaning of "sustainability" in this work refers to essential moral values about to ensure that it reaches the most advantageous proposal and avoiding maneuvers, which affects throughout the public safes, before and during accomplishment of the contract. The fact is that to implement the compliance systems, which seek for ensuring ethic, companies need to invest in human resources that require investments leading to a higher final cost of the goods and services offered by them. Therefore, the idea is that there are advantages for companies which have implemented the compliance systems.

Looking forward to ensure the ethic of the companies involved, it is believed that the principle of transparency and the duty of information must reach the principles of ethics always when it has involvement with public funds, because in such cases the society has the right to supervise the conduct of those people who have their benefits from public funds.

Considering the two points above (compliance systems and obligation of transparency and information for the companies involved) it is willing to analyze one another. Following this point, it is understanding that it is appropriated to investigate how the anticorruption law (federal law 12,846/13) and its subsequent decree (decree 8,420/15) deal with the duty of transparency and information. Finally, some considerations will be drawn aiming conclusions.

\section{OBLIGATION OF TRANSPARENCY AND INFORMATION TO THE PRIVATE SECTOR}

Initially, it has been considered some comments that comes to society knowledge by tools and technologies placed for the service of the advertising. As stated Dowbor (2003), the best system is neither the authoritarian, because in this system the state decides by the citizen, nor the liberal, in which the citizens have absolute freedom to choose. However, the state does not need to provide

\footnotetext{
${ }^{2}$ About this perspective, check out Freitas (2015).
} 
them informations to consciously decide the causes and consequences of their choices. Thus, the best system is the one in which the state takes care to provide citizens information to make their choices aware of the risks and benefits. Moreover, the author says that there are no missed information, however, there are much information but also much irrationality, so that:

The problem results from its irrationality and not from its lack of information. We citizens are submerged with informations and pictures about horrendous crimes happening in the cities. We started to be locked at home and to buy more fences. At the moment when everybody is buying fences, the advantage is none and also we remain unsafe. The solutions is in the root of the problem, in the miserable suburbs, in children who drop out of school, and other processes in which we remain dramatically misinformed. We need socially organized information enable to informe action by citizens, companies, civil servant, the civil society organization. (DOWBOR, 2003, p.2)

Then, it is not enough only to have a large number of information, which are easily accessed nowadays. This number of information has to be managed to be used as resources for rational choices, in other words, the rationality choices depend on rationality informations. In this sense, it should be investigated how much a large number of information contributes to build articulated society, aware of their obligations and rights.

Dowbor (2003, p.4) warns that too much information makes the society confuse, and also the good and needed information get lost in this immense universe. In contexts like this, "The challenge that arises is the organization of information according to the practices of social actors which intervene in the social development process." Finally, the task is to organize the information that is relevant to citizenship and for sustainable developmentl $\left.\right|^{3}$.

Consequently, the information is a key condition for the construction of democracy process and it also involves the transparency, not only in government decisions, but also the companies, social organization, etc. Much more important to make this observation when it comes to control the corruption, according as the companies also become target of concern due to the relations with the government. Often these relationships, which appear to be a simple construction or supply contracts, in fact are ideological political nature that gets place in political agenda, influencing the choices of the public policies.

According to the necessity of organize information and of easy understanding, it is noticed, for instance, that when budget laws are published they will rarely be understood by citizens, given the complexity of the information. Then, the transparency of the state, economic and civil society sector

\footnotetext{
${ }^{3}$ From this perspective, the author highlights an improvement in areas such as health, education, economy. However, he identifies the lack of organized information and easily accessibility to issues of democratization in decision-making processes. Indicating the criteria outlined by Robert Putnam: 1 . Measures of the level of organization of community life; 2 . Measures of engagement in public affairs; 3 . Measures of participation in voluntary work; 4. informal sociability measures; 5 . Social Confidence-building measures (DOWBOR, 2003, p.7)
} 
have to deal with the information that was given to them by the intelligibility of the data served. Therefore, the citizen will be able to effectively exercise their fundamental right to information.

Building trust in democratic institutions depends on bringing the public the management of the public interests, and these can be managed by the state itself or by the private sector. Thus, all of those who work, either directly or indirectly, with the public sphere are part of this management of interest. So that everyone should be subjected to those constitutional principles, except the intimate areas also enshrined in the Brazilian Constitution. There is no talk about democratic state without an advertising culture in all areas that are related to the public interest.

At the moment when it is dealing with the fundamental right to information ${ }^{4}$, the expressions transparency and publicity appear very often. For this reason, it is necessary to warn that between them there is a relationship of genus and specie and the advertising has being a kind of genre transparency. The advertising involves many variations, such as advertising of administrative processes, contemplates in the Law 9,784/99; the advertising, except in confidential cases of judicial proceedings; the duty to publish the laws in the official press (or in other journals, for those cities that do not have official press); the advertising in the Legislative sections; the duty to publish all the expenses, as the Transparency Law (Federal Law n 12,527/11).

It is important to say that those values are connected to the idea of accountability, considering that accountability needs a juridical and technical support that allows it no convey information relating to public administration, so that, the civil society can supervise itself and the state. Also, it is obviously known that the social control needs informations to control.

In Brazil, the advertising has taken a central role, since the Constitution of 1988 in which at many times includes the advertising ${ }^{5}$, and since 2011 the Transparency Law (Federal Law $\mathrm{n}$ 12,527/11). However, it is still noticed a lack of involvement of citizens in the presented information. Several factors may be creating this situation, but a very common problem is the fact that those informations only are used by the media with the scope of promoting political scandals (FILGUEIRAS, 2011). This public logic for the public management brings a political apathy process in citizens due to lack of trust in the government, because of these scandals.

The media, specially the television, fights for points in IBOPE (Institute of Public Opinion and Statistics) and to reach a good result, it worth to present the viewer any event that catches its attention. Then, at the time when the viewers have access to political scandals, they have only a point of view selected and elaborated by the news report. The outcome of the case is almost always given from the media without caring about showing how the case was solved, what sanctions were applied, etc. Thus, the news is in media spaces for a few days, making the authorities to not have enough time to ascertain the facts in accordance with the limits imposed by the democratic State Ruled by the Law. And, as it is needed to keep the viewer surrounded in new events, the media searches, finds and

\footnotetext{
${ }^{4}$ About the effectiveness of the fundamental rights, see MARCO; HUMENHUC, (2015).

${ }^{5}$ Explicitly in the caput of Article 37 of the Federal Constitution.
} 
conveys more political scandals ${ }^{6}$. This situation is common in Brazil, it makes harder, if not impossible, to build the necessary confidence for the solidification of the Brazilian Democracy.

The investigative activities of the media contributes to democracy, of course. It revels events which start the authorities investigations. However, what is not democratic is the public authorities setting their agendas according to the complaints of the media. Then, instead of solidifying democracy, it just generates a disparaging environment in which it seems that the corruption rule the state. And worse, the citizens find themselves helpless facing such a large sample, and therefore, they stop to rely on mechanisms democratic as a way to control the power. Also, it is not democratic to let the transparency to be appropriated only for the media, because the goal of the transparency is to inform civil society about how the collective interests are being managed. Therefore it is up to the transparency to take these informations and evaluate the results and concrete actions.

The fact is that the media is a space with lack of democracy, making many of the presented information to camouflage ideologies and other interests that are not disclosed. Therefore, a feasible measure to take would be to implement an automatic system to receipt information, similar to the push system of STF and STJ, which seems to fit perfectly as a tool to democratize the access to information and also to make easy the exercise of this right. In addition, it is needed to make easy to understand the received information, leaving the technical language away and choosing an understandable language to people.

From this perspective, Martí (2006) when deals with the importance of the information to enable deliberative democratic spaces, warns of the risks of the informal resolution (non-institutional), although it can relate with a more effective participation of citizens, it is very subject to the influence of agents that have the economic and intellectual resources used to manipulate the public opinion in their favor. Through such influence, those agents can make the public policy in favor of hegemonic groups, and also they get all the legitimacy because they have the support of society, which does not notice those ideologies that such policies hide. Therefore, it is concluded that "The manipulation of preferences that occurs through the speeches of the media has worse consequences in a democratic society, that does not regulate aspects of political communication" (MARTí, 2006, p. 115). It is admitted that all democratic models are subject to ideological manipulation, but the media does a harmful manipulation.

Filgueiras (2007) argues that there is an important relationship between advertising and confidence. He says that even though it is not required that the common man and politics need to be moralist, and within the private sphere it is assumed secrecy (which it cannot be invaded by the general public). However, when those news are related to community affairs, they have to be treated in public, because it is the wide dissemination that makes viable the trust in institutions and in tools offered to social control. Finally he states that:

\footnotetext{
${ }^{6}$ Just to quote one example, a major national magazine that goes on newsstands on Sunday caused the loss of political offices at the national level, as ministers, and soon their copies came out to the streets. It created a predicted situation, people who the magazine would report might lose its job, so that the country's president had not shaken its reputation.
}

Revista do Direito [ISSN 1982-9957]. Santa Cruz do Sul, v. 2, n. 49, p. 116-130, maio/ago. 2016. https://online.unisc.br/seer/index.php/direito/index 
[...]Because it becomes a central element to measure the political institutions virtues. It means that virtues institutions are those that can manage a trusted context on the principles of publicity and the protection of private autonomy. [...]

The function purpose of trust in advertising is to keep intact the existence of secret societies and sociability patterns that give notion of belonging to a formal community. (MARTI, 2006, p.879)

The tension between opposing interests is typical of democratic state ruled by the law. This situation is very evident as the advertising dismemberment of the right to information, because the private sector aims to confidentiality and privacy, which reduces chances of building trust; the opposite occurs in the public sector, which the advertising has to achieve even higher levels. But to set the public and private sectors, the 2002 Civil Code is not enough when it deals with legal entities ${ }^{7}$. Because it is too simple even knowing that the legal entities of the indirect public administration will be handled by private law, which the Article $173^{8}$ of the Federal Constitution of 1988 established. The 2002 Civil Code cannot be used because, for example, it would require the legal entities to take civil service examination for hiring new employees. This example demonstrates the insufficiency of treatment by civilian law. In addition to the civil law definition, it is needed to identify the existence and prevalence of the public interest, even facing companies. Making companies subject to certain imperatives of public law, checking if they are being transparent and providing informations related to such contracts and agreements. Through this way, the possibilities of corruption practices will be reduced, allowing the civil society to supervise those contracts. Also allowing the concurrence to make controls, enabling the interested companies in the dispute to monitor and report when they find moral deviations in the contracts. Then, it can be concluded that legal entities from the private sector that

\footnotetext{
${ }^{7}$ Art. 40. The public entities have internal or external rights, and private right.

Art. 41. Legal entities of public law are:

I - the Union;

II - the States, the Federal District and the Territories;

III - Municipalities;

IV - municipalities, including public associations;

$\mathrm{V}$ - other public character of entities created by law.

Single paragraph. Unless otherwise specified, legal entities of public law, in which have given private law structure, regarding its functioning, the rules of this Code.

Art. 42. External States and all the people who are governed by international law are external public legal entities right.

${ }^{8}$ Art. 43. The legal entities of internal public right are civilly responsible for acts of its agents which cause damage to third parties, except regressive right against who caused the damage, if any, on their part, negligence or willful misconduct.

Art. 44. They are legal entities of private law:

I - associations;

II - corporations;

III - the foundations.

IV - religious organizations;

$\mathrm{V}$ - the political parties.

$\mathrm{VI}$ - the individual limited liability companies
}

Revista do Direito [ISSN 1982-9957]. Santa Cruz do Sul, v. 2, n. 49, p. 116-130, maio/ago. 2016. https://online.unisc.br/seer/index.php/direito/index 
have access to public funds are subjecting themselves to be more rigorously to the principle of public morality of administrative law.

According to Taborda (2006, p. 66), the advertising of the administrative acts became into "indispensable condition for the moral legitimacy of politics and democracy by the interests between rulers and ruled." In this sense, it can be called democratic political system by the society. The author Kant warns that the principle of advertising is more than an ethical principle, but it is also a legal principle that belongs to the law. Given the advertising that the politic requires, the author states that the use of rationality possibilities people to understand about Republic issues. In addition, it is essential to use the rationality because the population will have enough knowledge to agree or rebel against the government. Although the author says that this principle applies to the state, in this article it also applies to companies that contract with the government.

From this point of view, the fundamental right to information is a result of the republican principle, as the elected representatives do not act for personal gain, but to serve the common good and to protect the collective goods. Hence, giving advertising to the acts relating to the public interest is a form of accountability, for this reason, the accountability depends on the advertising, because it only exists if the state and all involved with the government are committed to advertising their actions.

The citizen rarely acts directly with the state management, the social control only can be realized if the citizen has knowledge about how this activity has being performed. Increasing the actual chances of social control is important because the forms of social participation are restricted before the whole amount of responsibilities that the state has, and even if it is faced with sort of participation, the state should also take care of the social control because the civil society decides and must examine whether its decisions are being implemented and to assess whether the results are positives, also, in order to correct any errors in the collective decisions.

Rewording Kant (apud TABORDA, 2006), the politic turns to be moral from its advertising and when politicians open to be evaluated by their authors, with very few exceptions, only the acts that content against the public morality are kept in secrecy. The duty of information, as well as the duty of transparency and advertising, cannot rely on citizen requests. The information has to be offered and be available to anyone who wants to learn and get involved, without barriers, clearly, and easy understanding for everyone. ${ }^{9}$

The trust protection principle is irreconcilable with surprises coming from the state, therefore, nothing is more justifiable that the exercise of the right to information is possible by advertising and transparency, always thinking of the most effective ways to ensure it. At same time, it is needed to think about ways that these contents are appropriate for civil society to get control by itself, because when the control is in charge of the bureaucracy or media responsibility, it barely contributes to consolidate the democracy. Hence the needed to think about social control mechanisms.

Therefore an important role is up to the law, as it was given by Kant (2010, p.75), through the law it is necessary a relationship between ethics and politics. 9 In this relationship, the advertising "is contained in any legal claim, because without it, there would be no justice (which can only be thought as publicly reportable), therefore neither would have any right that is only granted by it" (emphasis in

\footnotetext{
${ }^{9}$ About Kant, VEGAS (2015)
}

Revista do Direito [ISSN 1982-9957]. Santa Cruz do Sul, v. 2, n. 49, p. 116-130, maio/ago. 2016. https://online.unisc.br/seer/index.php/direito/index 
original). The advertising, for Kant, is a duty of the Republican State, so that content that is hided because of fear of reprisal citizens, violates public moral law and therefore, clashes with the values enshrined by Republic advocated for it. Based on this, there is a following categorical imperative "All actions relating to the right of other men whose maximum do not be reconciled with advertising are unfair" (emphasis in original) (KANT, 2010, p. 76). Then, Kant gives examples, with the scope of national and international legislation, to demonstrate the rationality and university of this imperative, which will not be analyzed in this paper. However, it is emphasized that Kant defended the advertising duty in a wise meaning to say that "all actions relating to the right of other men" (KANT, 2010, p. 89), then when companies contract with public authorities, their actions reach the right of other men.

Then, the idea defended here is that the state, and those with contract with it, cannot act protecting private interests decoupled of public interest. It is linked to the implementation of the fundamental right to information guiding for the maximum transparency, making its public actions because the advertising is a way to harmonize the policy with the public morals, making the confidential to hide actions of public morality, and then escaping from the social disapproval.

It is noticed from this way that only reprehensible conduct are omitted and concealed, a situation that cannot be accepted by the Republicans. Therefore, the advertising (by Kant's point of view) seems to be a transcendental principle that allows to harmonize the politics with morality, which is a noble value to Democratic and Republican States.

The current time reserved to the state and society the difficult task of reconciling privacy with advertising: the same way that the state activities must be transparent and open to knowledge, critics and watched by society; in the private sphere the confidentiality and secrecy prevails. Therefore, the advertising as consequence of morality that is defended, here is public. In private life, human being has freedom to guide its conduct by values that make it happy, so its sexual, family and professional choices are protected by secrecy and freedom.

Having the idea of right/duty of information that was defended in this report, the social control may fall on the ethical sustainability of companies, however it is up to the Law the role to achieve this ideal, imposing obligation for the private initiative to act transparently. Following it will be a discussion of the Anticorruption and its regulations with the scope of assess how it has been happening.

\section{THE ANTICORRUPTION LAW AND ITS REGULATIONS FROM THE OBLIGATION OF TRANSPARENCY AND INFORMATION FOR PRIVATE INITIATIVE}

Traditionally the activity of control of corruption is predominantly to the State, especially in the figure of administrative agents and political agents. However, this approach is unidimensional suffering changes, having as its horizon the perception that the corruptives practices depend on the conjunction of two or more wills: one is expressed by the private agent who wants to optimize your profit and accelerate administrative procedures, and both are willing to circumvent the laws of the States; and on the other hand is the public agent, which intentionally or not, is willing to collaborate with the private agent.

Revista do Direito [ISSN 1982-9957]. Santa Cruz do Sul, v. 2, n. 49, p. 116-130, maio/ago. 2016. https://online.unisc.br/seer/index.php/direito/index 
It so happens that this system disentangle and assists the expansion of capital only in a first moment, while the modus operandi of these practices are unknown, and only a group quite limited has privileged access to them. Overcome this initial phase, the private initiative started to identify the losses of corruption, that, after expanding and being easy to access, ceases to be a facilitator of business with the public power and becomes a business quite expensive, of uncertain results ${ }^{10}$. In a certain way, the perception of this fact acts as a discouraging the corruptives practices, it is in line with what Corrêa defends: "The goal of the establishment of a national system of integrity is to make corruption - and illicit practices related - is of high risk and low return." (CORRÊA, 2011, p. 165).

Thus, the market is fighting against it, because to combat it, decreases the cost of transactions with the public. Under the economic, corruption becomes a villain not only of public resources, as well as of the private, since the transactions corrupt have a cost that cannot be declared, creates an environment of insecurity and instability for the investors, works with laws obscure and little known, among other damages. Hence arises, also for investors, the need to think measures for restraint it. However, cannot the private enterprise to carry out this task without having to his side an allied fort: the State.

With the intention of fighting against the corruption, the United States he was first one of the countries to be launched in the struggle against the corruption, through a politics of criminalização of the corruption. In 1977, this country promulgated the law Foreign Corrupt Practices Act (FCPA) what prohibits the enterprises subject to her of they pay bribe to the foreign government's employees and other agents, with the purpose of carrying out business with such states. (WOLD COMPLIANCE, 2014) The noncompliance of this law imposes civil and penal measures. It happens that this measured it ended up generating an unexpected effect: the american enterprises stopped being able to compete in some markets, specially in that where are the corruption levels high. Therefore, the United States proposed an international campaign of combat to the corruption having as main target restricts the corruption through the private enterprise.

So, it started to put pressure on the Organization for Cooperation and Economical Development (OCDE), that one of his objectives is "To contribute with a healthy economical expansion in the countries-members, as well as in the countries not members" (CGU, 2014) and created the Convention of $\mathrm{OCDE}^{11}$ with the objective to implement that specific objective.

The 2nd article of the Convention determines that "Each part should take all the necessary measures to the establishment of the responsibilities of legal entities for foreign public employee's corruption, in agreement with their juridical beginnings". In fulfillment to this device, the Brazil promulgated the Federal Law 12.846 of 1st of August of 2013, that disposes on the civil and

\footnotetext{
${ }^{10}$ ROSE-ACKERMAN (2001) it points out that the interest in itself is a factor motivador human universally, and the endemic corruption suggests a failure generalized in using these productive interests on behalf of objective, specially because the corruption reduces the effectiveness of the industrial policies and very often it imposes to the enterprises they act in the sector not officially, producing so a deficit of tax revenue and formal jobs, and, consequently, reduction in the resources to implement public policies. It is seen from there that it is not you punish him as for corruption "it diverts of public money", but several other effects that, right or indirectly, they finish by having repercussions on the financial limitation of the State in paying attention to the constitutionally supported social demands.

${ }^{11}$ Convention on the Combat of the Corruption of Foreign Public Employees in International Commercial Transactions.
}

Revista do Direito [ISSN 1982-9957]. Santa Cruz do Sul, v. 2, n. 49, p. 116-130, maio/ago. 2016. https://online.unisc.br/seer/index.php/direito/index 
administrative liability, of legal entities that will happen in acts practice against the public administration, national or foreign. This law was a result of the recommendation that the OCDE did to Brazil.

To cost to point out that leaving from there the private enterprise will have to domesticate his anxiety for profits (the reason that takes to corrupt legal systems and to use of unethical conducts), to guide their conducts for the ethics and for the respect to the national and international administrative norms. It has been, like this, the linking the ethical and moral values of both the public sector and the private sector. In other words, not only the public manager, whose to act is ruled in the persecution of the public interest, it should pursue the administrative morality; this link also reached the private sector agents, that, in the search for their private and economical interests, they cannot aim for the end (the profit) without observing the socially acceptable means guided by administrative morality.

This new paradigm was accompanied by another tendency: the compliance or like the Brazilian law it called systems of entirety. This one is occupied of creating mechanisms to be introduced in the enterprises, aiming to prevent and to fight illicit conducts in disagreement with the indications above described. For Maeda (2013, P. 167), the programs of compliance reflect them "efforts adopted by the private enterprise to guarantee the fulfillment of legal and regulation demands made a list to his activities and to observe beginnings of ethics and corporative entirety."

In the general form, the programs of corporative agreement are established on seven essential elements, they are:

(1) the establishment of standards and proceedings of agreement, (2) leadership of management of high level and supervision of the program of agreement and ethics, (3) delegation of powers for the authority responsible for the program, (4) measured to communicate standards and proceedings, (5) monitoring, auditing and practices of evaluation to reach the agreement and to secure the sufficiency of the program, (6) discipline, incentives and actions of inspection applied in the form to promote the fulfillment, and (7) organizational answers the bad-conduct with views to the future prevention of bad-conduct and deficiencies of the correction program. The orientations also demand that the seven elements are adjusted and implemented to the light of a periodic evaluation of risks. (Tradução livre) (MCGUFFEY; SOLDAN, 2014, p. 9-10)

These elements go to any program, independently of the size of the enterprise. It takes place that, initially, the programs of entirety (just as there are called the programs of compliance) were thought for the great corporations, so it is those who occupy the biggest spaces in the international media whenever they are wrapped in scandals. It is enough to remember the great repercussion of the set off cases of corruption wrapping the multinational German Siemens ${ }^{12}$. However, the entirety

\footnotetext{
${ }^{12}$ It follows passage of report "Last week, the Siemens had his revoked ethical stamp. The German multinational was one of the first four enterprises in the Register Enterprise in favor Ethics, and therefore owner of the stamp given by Controllership-General of the Union (CGU), in the year of 2011. The decision was in function of the denunciations of formation of cartel in the sector subway-railroad of São Paulo and of
} 
programs are not directed only to great corporations, so, as point out the americans McGuffey e Soldan (2014), programs must be developed in the certain measure for the size of the enterprise. So, they propose a compatible program with the size and the resources that each enterprise arranges, since there cannot be despised the cost that such programs demand.

The justification of thinking appropriate programs for smaller companies, the authors rests in as "Between 2000 and 2005, for example, great most of the condemned organizations were those with less than 200 officials." (Tradução livre) (MCGUFFEY; SOLDAN, 2014, P. 8). The main adjustments for the smaller companies are in the following aspects: to disseminate the execution culture inside of the organization, and to remind that organization of small and medium load is much more dependent of her top administration because they have less administration levels, fact that it increases the transparency of the decisions taken by the high administration. Instead of an organization without face, employees of smaller organizations tend to know the high administration and her ethics of businesses and administration style.

The compliance programs are not imposed it any company, however, some legislations have been creating mechanisms of reduction of the effects of the sanctions, could arrive to total exclusion of the responsibility of the legal entities, when they have implanted good systems of fomentation of the ethics in the relationships with the public power.

Example of that is the English law UK Bribery Act, in force from 2010. This law makes responsible the companies that committed practices considered corrupt, however, if it proves the enterprise what had introduced a program of compliance, the responsibility of the legal entity, to whom there was linked the subject author of the illegal act, it will be able to be forgiven. There are realized two effects of the english law: turned more severe the feathers to the legal entities that, in the longing of negotiating with the public power end up offering advantages for the public agents; and, on the other side, it reduces the sanctions if the offender (legal entity) to demonstrate what had programs adapted to inhibit his employees and representatives of acting according to standards ethical and legal regulated in internal standards, as for example, ethics codes. (MAEDE, 2013)

In Brazil, though the "culture anticorruption is still not spread" (CLAYTON, 2013, p. 153), significant advancements are reached. In such a context, one compromised with the international community in there collaborated with the combat politics to the corruption that, between other

Federal District. The Siemens it had still his name included in the list of enterprises disreputable and suspended, maintained it shears controllership." Available in <

http://www.jb.com.br/pais/noticias/2014/03/17/corrupcao-caso-siemens-e-as-propinas-do-metro-paulista/ >. Accessed in: 19 set. 2014. Besides the case wrapping Brazil, in 2006 the enterprise was if wrapped in another scandal, as it reports the next report: "In November of 2006, a great scheme of payment of tips came to the surface, leading to the removal of practically the whole directorship in the first semester of 2007.

In reply to the problem, the enterprise adopted a program anticorruption, and the new management, under president Peter Löscher, guaranteed what would prefer to open hand of profitable business to have again what will launch hand of illicit practices.

But a new case in Brazil seems to expose the difficulty that the enterprise hosted in Munich has in turning words into acts. In the last week, the Siemens notified the authorities antitrust Brazilians on a cartel formation, with participation of the German multinational, to defraud bidding for the purchase of railroad equipment and for the construction and maintenance of lines of train and of subway in Sao Paulo and in Brasilia." Available in:< http://www.dw.de/esc\%C3\%A2ndalo-no-brasil-p\%C3\%B5e-em-d\%C3\%BAvida-esfor\%C3\%A7osanticorrup\%C3\%A7\%C3\%A3o-da-siemens/a-16961389>. Accessed in: 19 set. 2014.

Revista do Direito [ISSN 1982-9957]. Santa Cruz do Sul, v. 2, n. 49, p. 116-130, maio/ago. 2016. https://online.unisc.br/seer/index.php/direito/index 
measures, published Law Anticorruption in 2013 and in 2015 it was regularized, carrying out so the international direction.

Firstly, the above-mentioned law did not advance, as it takes place in England, Spain and the United States, regarding the penal responsibility. The Brazilian law preferred offenders of his expressed ones did not trouble criminally the legal entities. That has been the object of criticism, because for some should have followed the international trend ${ }^{13}$. However, for different, it would have few practical effects, since the main penal sanctions are the restrictive ones of freedom, which are impossible of being applied to legal entities. Too many sanctions, like fines, the administrative and civil responsibility notice of promoting. As Capanema (2013), the administrative and civil processes are faster, and therefore the possibility of penal responsibility might hamper others two processes.

The law goes both to the national legal entities and to the foreigners who have any activity in Brazil. The article 2nd of the Law contemplates the objective responsibility of such persons, in other words, does not depend of proving fault or fraud in practice of the acts. In this sense, quilting stitch that there is proved the action or omission (in this aspect the compliance will have important effect), the damage, material or not, to the State, and the connection between the action / omission to the damage, in other words, the causal connection, in order that the sanctions were applied. The responsibility imposed by the law, can be perfected though the authors of the fact have not been identified. And if his authorship is being investigated in the judicial extent, that does not interrupt it does nor lift the progress of the administrative process imposed by the Law Anticorruption. Referent to the authors of the breaches, the incidence of the law anticorruption does not exclude the personal responsibility of the authors, individual entities, in other responsibility spheres. In this way, the authors, will be able to be held responsible civilly, penal and administratively. That does so that the legal entity has no advantage in omitting the suspect agents of having infringing the law, on the contrary, if they collaborate with the investigations they will be able to be benefited with the reduction of the predicted sanctions.

Concerning the integrity system, the Law Anticorruption missed the opportunity to better regulate the compliance instruments, since only brought in Article 7, section VIII that the existence of mechanisms and internal integrity procedures, audits and irregularities complaints can attenuate administrative sanctions. It should have described these measured taking into account that is not enough to allege the existence of a compliance program, if this is insufficient or just to exist formally. The only paragraph of this article arranges that the regulation of the Federal Executive Power will be going to describe the parameters for the calculation of the administrative sanctions. In fulfillment to this imposition in March of 2015 the Decree 8.420 came into force, which also dedicated insufficient treatment and detailing to the programs of compliance, what still need to be better understood in Brazil, since there are treated as a new instrument and, due to the benefits that they have, can be used like form of 12 escapes of the rigidity of the sanctions predicted in the Law. 846/2013. They are important instruments to implement a culture ethics in the private field, he has seen what previously it was worked.

\footnotetext{
${ }^{13}$ Represent this current, among others, COSTA; FERNANDES (2014).
} 
One of the important faults, under the optics of this work, refers to the fact of not having predicted bigger publicity in the processes investigative. If the judicial process this one covered by the mantle of the publicity, should the administrative process also to be subjected to him. In this sense the Law Anticorruption (Law n. 12.846/13), in the 6th article it carries out, in certain measure, this direction. In the second clause it imposes the obligation of "extraordinary publication of the condemnatory decision", which will take place to expenses of the legal entity, in media of great circulation in the area of the practice of the breach and of acting of the legal entity or, in his lack, in publication of national circulation, as well as through edict fastening, for the least term of 30 (thirty) days, in the establishment itself or in the place of exercise of the activity, of visible way to a public, and in the electronic siege in the world-wide computers net. This imposition, allow that the civil society knows the breaches that the enterprise committed and, leaving from there be able to be more attentive in controlling other contracts that the public power comes to do with her. In the article 24 of the decree $8.240 / 15^{14}$ was better detailed the term and the number once and for all that will take place these publications.

To do this control, the Law also created the National Register of Punished Enterprises (Cnep). Referent to the cadastral organs, the decree regularized in the article 43 the National Register of Enterprises disreputable and suspended - CEIS - destined to subject relevant to contracts and bidding; the National Register of Punished Enterprises - Cnep - that will contain referring informations the enterprises punished in administrative process of responsible (PAR) foressen in the Law Anticorruption. However, two legal instruments in analysis lost the opportunity for giving bigger publicity to the informations referring to the punished enterprises and too much informations that compromise the public moral that comes to the surface in the PAR, given that neither the Anticorruption Law, neither his decree regulatory, they predicted the possibility of the population to accompany the progress of the processes or to ask for informations referring to him. Only to ends of demonstrating this affirmative, the article 48 of the decree determines that "The supply of the data and informations of which they treat the article 43 to article 46 , for the organs and entities of the Executive, Legislative and Judicial Powers of each one of the spheres of government, will be disciplined by Controladoria-General of the Union.". In this way, the informations necessary for the rational choices and the sustentabilidade ethics will not be appropriated by it by the civil society, the biggest interested one in doing the control of the corruption.

It was lost so, a great opportunity to impose the duty of transparency and of information for the enterprises that they employ with the public power, so noble values to build a culture of extensive public morality both to the State and to the private enterprise. This situation limits the participation,

\footnotetext{
${ }^{14}$ Article 24 . The legal entity sanctioned administratively by the practice of harmful acts against the public administration, in the terms of the Law $\mathrm{n}$ - 12.846, of 2013, will publish the administrative decision in the form of extract of sentence, cumulatively: I - in means of communication of great circulation in the area of the practice of the breach and of acting of the legal entity or, in his lack, in publication of national circulation; II - in edict stuck in the establishment itself or in the place of exercise of the activity, in locality that allows the visibility for the public, for the least term of thirty days; and III - in his electronic site, for the term of thirty days and in distinction in the main page of the above-mentioned site.

The only paragraph. The publication to which the caput refers will be done to expenses of the sanctioned legal entity.
}

Revista do Direito [ISSN 1982-9957]. Santa Cruz do Sul, v. 2, n. 49, p. 116-130, maio/ago. 2016. https://online.unisc.br/seer/index.php/direito/index 
doing with what the important informations, how, for example, of a process of investigation of involvement of legal entity, they are not spread. The risk is taken, through this systematic one of what the institutional controls turn into the form of structural violence, in which they hardly show to secure the social participation, without, nevertheless, to have.

These acts notes, one leaves, next, to the final considerations.

\section{FINAL CONSIDERATIONS}

The idea is defended of having a politics that stimulates the implementation of system of efficient entirety in the interior of the enterprises, because of believing that the compliance is an important tool to secure the ethics in the public employment, as well as the information and the transparency, all, however, they need to be enlarged. Besides, the processes of responsabilização when Anticorruption was predicted in the Law need to have a visibility bigger than the regulations that today they receive, in way to allow that the civil society has informations referring to a PAR, to act like supervisors of the public morality. A significant opportunity was lost, so much in the decree how much in the law, to enlarge the duty of information and transparency of the enterprises that they employ with the public power, reason for which such legislative instruments did not bring advancements in the field of the transparency and information, so expensive values to the Brazilian society that looks to make his recent democracy real.

\section{BIBLIOGRAPHIC REFERENCE}

CAMPANTE, Rubens Goyatá. O Patrimonialismo em Faoro e Weber e a Sociologia Brasileira. Revista Dados, Rio de Janeiro. n.1 v.46 2003. p. 153 - 193, 2003. Available in: < http://www.scielo.br/cgi-bin/wxis.exe/iah/>. Accessed in: $28 \mathrm{dez} .1012$.

Controladoria Geral da União. Desenvolvido pela Controladoria Geral da União. Available in: <hhttp://www.cgu.gov.br/ocde/sobre/informacoes/index.asp>. Accessed in: 09 jun. 2014.

CLAYTON, Mona. Entendendo os desafios de Compliance no Brasil: um olhar estrangeiro sobre a evolução do Compliance anticorrupção num país emergente. In: ADEBBIO, A.D; MAEDA, B. C; AURES, C. H. da S. (Org.). Temas de anticorrupção \& Compliance. Rio de Janeiro: Elsevier, 2013. p. $149-166$.

CORRÊA, Isabela Morreira. Sistema de integridade: avanços e agenda de ação para a Administração Pública Federal. In: AVRITZER, L.; FILGUEIRAS, F. Corrupção e sistema políticos no Brasil. 2011. p. 163- 190.

COSTA, K. A.; FERNANDES, J. U. J. Breves comentários à Lei da Responsabilização administrativa e civil de pessoas jurídicas pela prática de atos contra a administração pública, nacional e estrangeira. In: NASCIMENTO, M. D. do (Org.). A lei anticorrupção empresarial: aspectos críticos à Lei no 12.846/2013. Belo Horizonte: Fórum, 2014. p. 29-58.

DOWBOR, Ladislau. Informação para a cidadania e o desenvolvimento sustentável. 2003. Available in:< http://dowbor.org>. Accessed in: 4 jun. 2014. 
FILGUEIRAS, Fernando. República, confiança e sociedade. In: Dados - Revista de Ciências Sociais, vol. 50, nำ 4, 2007, p. 863-897.

. Transparência e controle da corrupção no Brasil. In: AVRITZER, L. et. Al. (orgs). Corrupção e sistema político no Brasil.Rio de Janeiro: Civilização Brasileira. 2011. p. 133-162.

FREITAS, Juarez. Princípio da sustentabilidade: licitações e a redefinição da proposta mais vantajosa. Revista do Direito, Santa Cruz do Sul. v. 1, n. 45, p. 89-103, jan. - abri. 2015. Available in:< https://online.unisc.br/seer/index.php/direito/article/view/5890/4084>. Accessed in: 20 mar. 2016. KANT, Emanuel. A paz perpétua. Tradução de Marco Zingano. Porto Alegre: L\&PM, 2010.

MAEDA, Bruno Carneiro. Programa de Compliance anticorrupção: importância e elementos essenciais. In: ADEBBIO, A.D.; MAEDA, B. C.; AURES, C. H. da S. (Org.). Temas de anticorrupção \& Compliance. Rio de Janeiro: Elsevier, 2013. p. $167-201$.

MARCO, Cristhian Magnus de; HUMENHUK, Hewerstton. Os atos administrativos na sociedade de informação e a eficácia dos direitos fundamentais. Revista do Direito, Santa Cruz do Sul. v. 3, n. 47, p. 50-77, set.-dez. 2015. Available in:< https://online.unisc.br/seer/index.php/direito/article/view/5890/4084>. Accessed in: 08 dez. 2015. MARTÍ, José Luis. La república deliberativa: una teoria de la democracia. Madrid: Marcial Pons, 2006.

MCGUFFEY, Kristen; SOLDAN, Thomas C. Right-sizing: cusstimizing compliance to the small corporation. Available in: < http://webcache.googleusercontent.com/search?q=cache:vAZGMtFOh7YJ:www.pli.edu/emktg/complia nce_coun/Right_Sizing19.doc+\&cd=2\&hl=pt-BR\&ct=clnk> Accessed in: 21 ago. 2014.

ROSE-ACKERMAN, Susan. La corrupción y los Gobiernos: causas, consecuencias y reforma. Madrid: Siglo Veinteuno, 2001.

World Compliance. Apresenta informações sobre Compliance. Foreign Corrupt Practices Act (FCPA) Available in: <http://www.worldcompliance.com/en/resources/white-papers/foreign-corruptionpractices-act.aspx>. Accessed in: 01 jun. 2014.

VEGAS, Juan Castillo. El positivismo jurídico kantiana. Revista do Direito, Santa Cruz do Sul. v. 2, n. 46, p. 184-212, maio - ago. 2015. Available in:<

https://online.unisc.br/seer/index.php/direito/article/view/6016>. Accessed in: 23 jan.2016.

TABORDA, Maren Guimarães. O princípio da publicidade e a participação na administração pública. Tese de doutoramento. Porto Alegre. Universidade Federal do Rio Grande do Sul - UFRGS, 2006. Available in:

<http://www.lume.ufrgs.br/bitstream/handle/10183/7472/000545875.pdf?sequence=1>. Accessed in: mar. 2014.

\section{COMO CITAR ESSE DOCUMENTO}

FRIEDRICH, Denise Bittencourt; SBARDELOTTO, Fábio Roque. The fundamental right to the information and transparency in the anticorruption law: Is it going forward or backward?. Revista do Direito, Santa Cruz do Sul, v. 2, n. 49, maio 2016. ISSN 1982-9957. Disponível em: $<$ https://online.unisc.br/seer/index.php/direito/article/view/8078>. Acesso em: doi:http://dx.doi.org/10.17058/rdunisc.v2i49.8078. 